\title{
Practical Recommendations for Optimizing the Process of Formation and Development of Academic Mobility of Students in Higher Educational Institutions of Russia
}

\author{
Rimma R. Khanmurzina ${ }^{1}$, Oleg V. Sinitzyn ${ }^{2}$, Ayrat F. Kaviyev ${ }^{3}$, Elena A. Burdukovskaya ${ }^{4}$, Inessa V. Lebedeva ${ }^{5}$ \\ $\&$ Svetlana I. Ashmarina ${ }^{6}$ \\ ${ }^{1}$ Management and Law, Institute of Economics, Kazan, Russia \\ ${ }^{2}$ Kazan Federal University, Kazan, Russia \\ ${ }^{3}$ Yelabuga Institute of Kazan Federal University, Yelabuga, Russia \\ ${ }^{4}$ Amur State University, Blagoveschensk, Russia \\ ${ }^{5}$ Naberezhnye Chelny Institute of Social-Pedagogical Technologies and Resources, Naberezhnye Chelny, Russia \\ ${ }^{6}$ Samara State University of Economics, Samara, Russia \\ Correspondence: Rimma R. Khanmurzina, Management and Law, Institute of Economics, Kazan, 420111, \\ Russia.
}

Received: October 24, 2014 Accepted: December 3, $2014 \quad$ Online Published: December 18, 2014

doi:10.5539/res.v7n1p41

URL: http://dx.doi.org/10.5539/res.v7n1p41

\begin{abstract}
Academic mobility enhances the accessibility, quality and effectiveness of education and is an important tool for creating a global educational area and for supporting mobility of human capital. Therefore, this article aims to develop practical recommendations for optimizing the process of formation and development of academic mobility of students. The paper presents practical recommendations at the regional and university levels, allowing to organize the process systematically and holistically, purposefully uniting the efforts of all its subjects, and choosing priorities for action in accordance with individual and typological characteristics of certain students. Provisions of this article may be useful for teachers, management and staff of international departments of higher educational institutions of professional education.
\end{abstract}

Keywords: academic mobility, practical advice, the formation and development, students, higher professional school

\section{Introduction}

Academic mobility is an integrative quality of a person determined by political, economic, cultural, educational factors and characterizing the dynamic state of the individual able to adapt and respond to changes in the content and conditions of the educational activity, conscious of the need to develop his or her educational and professional creativity potential in the conditions of the Common Education Space (Tregubova et al., 2008).

Formation and development of academic mobility of students has been agreed with the leading national and international trends in the development and reform of higher education. Successful development of academic mobility of students is brought about by a number of conditions, defined by the normative documents of the Bologna process and by the process of higher education reform in Russia (Masalimova, 2008).

In the founding documents of the Bologna Process the need to develop academic mobility, as a basic condition for the formation of the European Higher Education Space, is constantly emphasized. The main goal of mobility is to give the student an opportunity to get a versatile "European" education in the elected field of study, provide access to recognized centers of knowledge, which have traditionally formed the leading scientific schools, to expand the knowledge of the student in all areas of European culture, to instill in him a sense of European citizenship. Mobility allows participants to take advantage of the wealth of the European area of higher education, including democratic values, diversity of cultures and languages, the diversity of higher education systems (Tregubova, 2009; Znovenko Land Makarenya, 2005; Khairullina, 2007).

Academic mobility cannot be equated to the concept of professional migration and the "brain drain", and is not 
limited to the acquisition of an international educational experience, as this type of mobility is aimed at an individual's acquisition and accumulation of experience in the design, implementation and change of their own educational and professional reality, taking into account the re-emerging environment for educational and professional goals within the national system of continuous education.

\section{Methodological Framework}

\subsection{The Key Position}

The methodological basis of this problem study is the position that the academic mobility of a future professional is an integrative characteristics expressed in the ability to overcome international language and cross-country barriers, quickly establish contacts, to adapt successfully to a different educational and professional area in line with the current requirements of society to a personality: dynamism, adaptability, rapid response and efficiency.

\subsection{Basic Principles}

Guiding principles for the formation and development of academic mobility of students are as follows:

- the principle of willingness to cooperate, assuming the willingness of subjects of the educational process, both domestic and foreign educational systems in developing effective strategic relations in the field of personnel training programs of academic mobility;

- the principle of mutual equivalent benefit, assuming a clear target orientation on the final equilibrium-significant product (mobile specialist), which is the same value for all the concerned parties (national and foreign higher schools) (Masalimova, 2008);

- the principle of collegiality, suggesting the effectiveness of social interaction of academic mobility partners, as well as the collective responsibility of concerned parties for decisions in order to avoid possible conflicts;

- the principle of functionality, involving international cooperation of Russian and foreign educational systems through participation in academic mobility programs, with simultaneous division of functions among them.

\section{Results}

We propose practical recommendations for optimizing development of academic mobility of students in higher education institutions at the regional and university levels.

\subsection{At the Regional Level}

- The creation of a regulatory development framework and implementation of double degree programs of academic mobility, of joint curriculums;

- Development and implementation of international programs and projects in the field of education and research activities in the education system (and, in particular, the definition of the legal status of international joint curriculums, including programs of double and joint degrees);

- Participation in the the system of training formation and retraining of personnel in the field of international cooperation in education;

- Definition of the establishment of documents equivalence not only on the appropriate education, but also on scientific degrees and academic titles obtained in foreign countries, and on the issue of certificates on the equivalence of the above documents (including the definition of a unified procedure for the issuance of the European Diploma Supplements and the solution to the recognition of the European Diploma Supplements issued by foreign institutions of higher education);

- Ensuring the established procedure of foreign citizens (persons without citizenship) admission for training, internship and professional development in the Russian Federation;

- Creation of incentives for institutional support development of high-quality academic mobility in universities (including academic mobility in the accreditation parameters number with mandatory qualitative evaluation of results).

\subsection{At the University Level}

- International cooperation of Universities: creation of joint curriculums (double degree programs); creation and implementation of the "external" programs of Russian Universities in Europe, Russia and other countries; exchange of students and teachers; joint development and implementation of innovative courses; joint seminars, conferences, summer schools; joint implementation of research projects involving the integration of the results into the educational process; establishment of different structural units with foreign partners (scientific and methodical centers, laboratories, technology parks and other similar structural units); organization of 
methodological seminars and conferences; development of teaching materials, publications, support of thematic portals; organization of public discussions and of project results distribution.

- Support for individual academic mobility of teachers: grants for Russian teachers who go to universities in other countries and for foreign teachers who come to Russian universities; practical studies for advanced training; development of new courses, syllabi, educational materials and textbooks; collection of materials for research or preparation of new programs; preparations for joint curriculums designing; participation in seminars and conferences; lecturing and conducting workshops throughout the semester (during three months);

- Support for individual academic mobility of students and post-graduate students: grants for Russian students and post-graduate students who go to study in foreign universities, and for foreign students and post-graduate students who come to study in Russian universities; training during a semester with the condition of learning outcomes credits transfer in the directing university; training throughout the year with the condition of learning outcomes credits transfer in the directing university; participation in summer schools; participation in conferences and seminars; collection of data for research.

- Organization of teaching activities: development and lectures of courses (compulsory course of lectures continued for two years after the grant agreement completion); support for special departments, conducting research; creation of excellence centers in research and teaching.

- Organization of research activities: support for university networks (research, conferences of associations, websites, and publications); support for young researchers to conduct research in Russia; organization of meetings, round tables and workshops for young researchers.

- Promoting the study of Russian and a foreign language: carrying out programs for foreign students in studying the Russian language at summer schools; special courses for students enrolled in Russia; programs for training in foreign countries, such as university-based and based on Russian cultural centers; development of specialized exams on the Russian language, teaching Russian students certain disciplines in a foreign language (Huseynov, 2005).

\section{Discussions}

To date, science has accumulated a certain fund of knowledge required to conduct pedagogical research on students' academic mobility formation in university education.

Study of the problem of academic mobility shows the variety of interpretations of this phenomenon, belonging to different fields of the humanities. At the root of the development of scientific bases for mobility problems there were Weber (1978, 1990), Giddens (1992) and Sorokin (2005). The content specificity of mobility diversity species is disclosed in the works of Brinev and Chuyanov (2001), Zaslavskaya (1974), Kugel (1983), Rybkina (1974) and Chernysh (2002). Sociological component of the academic mobility of a person is represented in the researches of Goryunova (2006) and Shchedrovitsky (2007).

Educational aspects of the academic mobility development of a person are addressed in the works of Russian (Baydenko, 2010; Bordovskiy, 1999; Verbitskaya, 2005; Veryaskin, 2005; Gevorkyan, 2004; Goryunova, 2006; Dzhurinsky, 2007; Zimnyaya, 2001; Znovenko, 2005; Kraynov, 2008; Lvov, 2011; Seleznyova, 2004; Tatur 2004) and foreign authors (Andris, 2002; Franco, 2004; Kron, 1991; Nyborg, 2004; Richardson, 1996; Underbill, 1989).

Priority in this field of research is the idea of the relationship of learning and development in the educational (Andreev, 2008; Gershunsky, 1997; Gustyahina, 2001; Ivanova, 2006; Kiryakova, 2004, 2005; Mityaev, 2005; Uflyand, 2004; Chernov, 1992) and professional training of a person (Zeer, Pavlova, \& Sadovnikov, 2004; Lavrentyev, 2002; Neudakhin, 2002).

A pooled analysis of sources on the issue has shown that in recent years the issues of academic mobility formation of students have been considered quite intensively. However, much less attention is paid to the development of practical recommendations for optimizing the development of students' academic mobility in higher education institutions.

\section{Conclusion}

Academic mobility of students represents one of the most important aspects of the Russian higher education institutions integration in the world educational area-both as professionally-oriented characteristic of future specialist, as well as a mechanism for successful adaptation of an individual to the changing conditions of social interaction and modern labor, and as a result of a specialist's professional development in multi-level competency education. 
Practical recommendations for optimizing the process of formation and development of academic mobility of students at Russian professional training institutions presented in the article allow you to organize the process systematically and holistically, purposefully uniting the efforts of all its subjects, and choosing priorities for action in accordance with the individual and typological characteristics of certain students.

\section{Acknowledgments}

The authors thank all participants of this study for their kind cooperation.

\section{References}

Andreev, V. I. (2008). Pedagogy of higher education (p. 500). Kazan: Innovation Center.

Andris, B. (2002). Academic cooperation and free movement of what was and what will be. Higher Education in Europe, 1, 2.

Baydenko, V. I. (2010). The main trends in the development of higher education: Global and Bologna measurement (p. 352). Moscow Research Center of the quality of training MISA.

Bordovskiy, G. A., \& Radionova, N. F. (1999). The concept of teacher education at the Russian State Pedagogical University (pp. 45-53). St. Petersburg: Herzen.

Brinev, N. S., \& Chuyanov, R. A. (2001). Academic mobility of students as a factor in the development of education. Ways of development of higher education in Russia (pp. 31-34). Omsk: GPU.

Chernov, J. K. (1992). Basics of designing educational technologies in a technical college (p. 155). Togliatti.

Chernysh, M. F. (2002). Social mobility and the Russian youth (p. 273). Israel.

Dzhurinsky, A. N. (2007). Integration of educational space in Western Europe. Human resources for innovation development of the educational system: Mat-ly I Vseros. Ped. Congress (pp. 25-29). Moscow: IASP.

Franco, M. (2004). Bologna process and EU Russian Relations. Russian Political Science Association, 10, 164.

Gershunsky, B. S. (1997). Philosophy of Education for the XXI Century (p. 181). Moscow.

Gevorkyan, E. N. (2004). The Bologna process and cooperation in the field of quality assurance: The experience of the Russian Federation. Education, 4, 150-165.

Giddens, A. (1992). Stratification and class structure. Sociological studies, 9, 112-123.

Goryunova, L. V. (2006). Professional mobility specialist as a problem of developing education in Russia (p. 427). Rostov.

Gustyahina, V. P. (2001). Contextual approach to the training of future teachers. Modern problems of science and education, 2, 29-31.

Huseynov, L. A. (2005). Globalization and socio-cultural development of regional systems of education. Higher education today, 4, 52-55.

Ivanova, V. I. (2006). The Bologna process and higher education in Russia. Pedagogy, 1, 97-106.

Khairullina, E. R. (2007). Orientation of students to self-development of core competencies in the design and creative activity. Science and Education Journal, 7.

Kiryakova, A. V. (2004). Status, problems and prospects of development of the international activities of the university (p. 60). Orenburg: IPK GOU OSU.

Kiryakova, A. V. (2005). Russia's integration into the international educational space (p. 40). Orenburg: IPK GOU OSU.

Kraynov, T. N. (2008). The Bologna Process and the problems of modernization of higher education in Russia. Success of modern natural science, 9, 76-78.

Kron, J. W. (1991). Yrundwissen pedagogic (p. 104). Muenchen.

Kugel, S. A. (1983). Professional mobility in science (p. 256). Moscow.

Lavrentyev, N. B., \& Lavrentiev, G. V. (2002). Innovative educational technologies in vocational training (p. 146). Barnaul.

Lvov, A. Y. (2011). Organizational-pedagogical conditions of formation of professional mobility of students Pedagogical University (p. 215). St. Petersburg.

Masalimova, A. R. (2008). Formation of academic mobility of students of higher technical school abroad: ideas, 
principles, performance criteria. Engineering Pedagogy, 9, 239-243.

Mityaev, A. M. (2005). Features of the system of training in the modern university. Pedagogy, 8(1), 71-73.

Neudahina, N. A., Lavrentiev G. V., \& Lavrentieva, N. B. (2002). Innovative educational technologies in vocational training (p. 231). Barnaul: Alt. State University.

Nyborg, P. (2004). The Bologna Process on the Way to Berge. Kazan State University, 15, 196-197.

Richardson, J. (1996). Learning the way to the cooperative school. School team innovator, 1, 2-6.

Rybkina, R. V., \& Zaslavskaya, T. I. (1974). Labor mobility as a matter of economic and sociological research (p. 57). Novosibirsk.

Schedrovitsky, G. P. (2007). Lectures on pedagogy (p. 400). Moscow.

Selezneva, H. A. (2004). Reflections on the quality of education: the international dimension. Higher education today, 4, 35-44.

Sorokin, P. (2005). Social mobility (p. 588). Moscow: Academia.

Tatur, Y. G. (2004). Competence-based approach in describing the results of the design and standards of higher education (p. 18). Moscow.

Tregubova, T. M., Sakhiev, R. G., Masalimova, A. R., Rafikova, E. M., Beljakin, A. M., Fakhrutdinova, A. V., \& Tazutdinova, E. H. (2008). Academic mobility of students as a factor in the preparation of a competitive specialist in the context of the Bologna process. Kazan: Danis PPIs RAO.

Tregubova, T. M. (2009). Formation of academic mobility of students of vocational schools in the face of international educational integration. Vocational education in Russia and abroad, 1(1), 35-39.

Uflyand, I. E. (2004). Bologna process: Content, regulations and guidelines for implementation (p. 300). Rostov-on-Don: WPC.

Underbill, A. (1989). Process in humanistic education. ELT Journal, 43(4), 250-260. http://dx.doi.org/10.1093/elt/43.4.250

Verbitskaya, L. A., \& Kasevich, B. B. (2005). On the modernization of Russian higher education: Current problems and possible solutions. Education, 4, 3940.

Veryaskin, V. P. (2005). Values and normative sources of the concept of human development. Man, 2, 41-45.

Weber, M. (1978). Economy and Society (p. 377). University of California Press.

Weber, M. (1990). Basic sociological concepts (p. 237). Moscow.

Zaslavskaya, T. I. (1974). Methodological problems of sociological research on labor mobility.

Zeer, E. F., Pavlova, A. M., \& Sadovnikov, O. N. (2004). Proforientologiya: Theory and Practice (p. 304). Ekaterinburg: Business book.

Zimnyaya, I. A. (2001). Key competences new paradigm of education result. Higher education today, 5, 3442.

Znovenko, L. V., \& Makarenya, A. A. (2005). Academic mobility of students as a factor in the successful establishment of professional competence of future teachers (pp. 105-109). Petersburg: GNU RMAs RAO.

\section{Copyrights}

Copyright for this article is retained by the author(s), with first publication rights granted to the journal. This is an open-access article distributed under the terms and conditions of the Creative Commons Attribution license (http://creativecommons.org/licenses/by/3.0/). 